\title{
Antimacrofouling Efficacy of Innovative Inorganic Nanomaterials Loaded with Booster Biocides
}

\author{
Eldad Gutner-Hoch ${ }^{1,2}, *$, Roberto Martins ${ }^{3}$ (D) , Tania Oliveira ${ }^{4}$, Frederico Maia ${ }^{4}$, \\ Amadeu M. V. M. Soares ${ }^{3}$, Susana Loureiro ${ }^{3}$ (D) , Chen Piller ${ }^{1}$, Iris Preiss ${ }^{1}$, Michal Weis ${ }^{1}$, \\ Severine B. Larroze ${ }^{5}$, Tania Teixeira ${ }^{5}$, João Tedim ${ }^{6}$ and Yehuda Benayahu ${ }^{1}$ \\ 1 School of Zoology, George S. Wise Faculty of Life Sciences, Tel Aviv University, Ramat Aviv, \\ Tel Aviv 6997801, Israel; pillerchen1@gmail.com (C.P.); irispreiss@gmail.com (I.P.); \\ weismichal@gmail.com (M.W.); yehudab@tauex.tau.ac.il (Y.B.) \\ 2 Interuniversity Institute for Marine Sciences in Eilat, Eilat 88103, Israel \\ 3 Department of Biology and CESAM, University of Aveiro, 3810-193 Aveiro, Portugal; roberto@ua.pt (R.M.); \\ asoares@ua.pt (A.M.V.M.S.); sloureiro@ua.pt (S.L.) \\ 4 Smallmatek-Small Materials and Technologies, Lda., Rua Canhas, 3810-075 Aveiro, Portugal; \\ tania.oliveira@smallmatek.pt (T.O.); frederico.maia@smallmatek.pt (F.M.) \\ 5 AquaBioTech Group Central Complex, Naggar Street, Targa Gap, Mosta MST 1761, Malta; \\ sbl@aquabt.com (S.B.L.); tpt@aquabt.com (T.T.) \\ 6 CICECO_Aveiro Institute of Materials, Department of Materials and Ceramic Engineering, \\ University of Aveiro, 3810-193 Aveiro, Portugal; joao.tedim@ua.pt \\ * Correspondence: eldad.hoch@gmail.com; Tel.: +972-3-6409090
}

Received: 31 October 2017; Accepted: 2 January 2018; Published: 10 January 2018

\begin{abstract}
The application of nano-structured compounds has been increasing rapidly in recent years, in several fields. The use of engineered nano-materials as carriers of antifouling compounds is just beginning and already reveals clear advantages compared to bulk active compounds, such as slowed and controlled release, novel functionality, and high loading capacity. This present study assesses the antifouling efficacy of two nanostructured materials, spherical mesoporous silica nanocapsules (SiNC) and $\mathrm{Zn}$-Al layered double hydroxides (LDH), loaded with two commercial biocides, zinc prithione $(\mathrm{ZnPT})$ and copper pyrithione ( $\mathrm{CuPT})$. The study used adult mussels from three geographical regions, the Atlantic Ocean, Mediterranean Sea, and the Red Sea, to examine the efficacy of the innovative compounds. The efficacy of these compounds on larvae of the bryozoan Bugula neritina from the Mediterranean Sea and the Red Sea was also examined. The results of this study demonstrated the environmentally friendly properties of unloaded LDH against the two-model systems, adult mussels or bryozoan larvae. ZnPT entrapped in LDH demonstrated the most effective antifouling compound against the two model systems. A comparison of the impact of the two compounds on macrofouling organisms from the different marine habitats examined in this study indicates a distinction associated with the organisms' different ecosystems. The Red Sea mussels and bryozoans, representing a tropical marine ecosystem, yielded the highest efficacy values among tested Atlantic Ocean and Mediterranean Sea mussels and bryozoans.
\end{abstract}

Keywords: fouling; antifouling nano-structured compounds; layered double hidroxides; silica mesoporous nanocapsules; pyrithione

\section{Introduction}

Biofouling is a natural process that relates to the gradual adhesion, accumulation, and growth of a variety of organisms on submerged surfaces $[1,2]$. The colonization of such surfaces begins with the conditioning of the substratum by dissolved organic compounds derived from the ambient seawater [3]. 
Fouling organisms may then start to colonize the surface, including microfoulers ('slime') comprised of unicellular microorganisms (e.g., bacteria, cyanobacteria, diatoms and protozoa), and macrofoulers (e.g., seaweeds, benthic soft or calcareous invertebrates) [4]. Currently, anti-fouling paints are the most efficient means to prevent and control the fouling process in the marine environment [5]. The key component of these protective coatings is an active compound used in the antifouling coating-related technology [6]. At present, the antifouling active elements are diverse and range from the widely used metallic antifoulants and organic booster biocides [7], surface-structured compounds [8], protein adsorption inhibitors [9], quorum sensing inhibitors [10], and natural biocides [11], to microorganisms with antifouling properties [12]. The coating formulation enables maximizing the performance of the antifouling paint.

The current study engaged with the efficacy of novel antifouling engineered compounds. Their innovation lies in the encapsulation and immobilization of the biocides (active compounds) in low toxic "smart" nano-containers. This enables the controlled release of the biocide and, therefore, provides a safe environmental loading of the biocide together with specific targeting. A similar technology of nano-containers loaded with active compounds is already used in drug delivery [13], medical sensory applications [14], and for protection against corrosion [15]. Similarly, the technology of nano-containers for antifouling purposes has been explored in order to assess antifouling applications. For example, Geiger et al. [16] encapsulated the antifouling biocide zosteric acid (ZA, $p$-coumaric acid sulfate), extracted from the seagrass Zostera marina, into polystyrene microcapsules and tested it on early stages of biofilm formation. Later, Hart et al. [17] encapsulated the broad-spectrum antifungal biocide 4,5-dichloro-2-n-octyl-3(2H)-isothiazolone (DCOIT) into polyvinyl alcohol and into phenolic resin due to the compound's low solubility in seawater. Szabó et al. [18] microencapsulated $\mathrm{Cu}_{2} \mathrm{O}$ and measured the adhesion of organisms on the applied surfaces by Acridine Orange Staining. Interestingly, Zheng et al. [19] developed $\mathrm{pH} /$ sulfide ion multifunctional released nano-carriers and loaded them with bacterial agents, thus resulting in anti-bacterial activity. The above examples, among others, demonstrate the potential application of encapsulating biocides for antifouling purposes.

For the purpose of the present study, two commercial biocides, zinc pyrithione (ZnPT) and copper pyrithione (CuPT), were successfully loaded into the versatile engineered nanomaterials (ENMs). These ENMs were spherical mesoporous silica nanocapsules (SiNC) and Zn-Al layered doubled hydroxides (LDH). SiNC features high thermal stability [20] and a typical diameter ranging from 100 to $200 \mathrm{~nm}$ [21,22]. LDH are anionic clays with a typical lateral-size ranging from 20 to $40 \mathrm{~nm}[15,23]$, functioning as host-guest materials [24]. Both nanomaterials have already been successfully used for corrosion protection [15,21-23] and more recently for fouling control, through the immobilization of different active compounds, including the above-mentioned pyrithiones, in the scope of the BYEFOULING FP7 project [25].

The ongoing development and production of nanotechnologies and nanomaterials reinforce the importance of assessing their toxicity, behavior, and their environmental fate. This is particularly relevant when nanomaterials incorporate biocidal activity with potential deleterious effects on marine organisms. Screening the efficacy and toxicity of the antifouling nanomaterials should include testing their effects on fouling species in different geographical regions, as well as their impact on non-target organisms. Mussels have been successfully used as a model system to screen antifouling compounds by examining their mortality and continued attachment to the substrate by byssus threads following the application of the compound [26,27]. An additional widely used model system for such assays is the bryozoan Bugula neritina, a cosmopolitan marine fouler [28,29].

The overall goal of the current study was to test the antimacrofouling efficacy of two nanomaterials, SiNC and LDH, loaded with copper pyrithione and zinc pyrithione, on the bryozoan B. neritina, from the eastern Mediterranean (MED) and Eilat, Gulf of Aqaba, northern Red Sea (RED), on the mussel Mytilus galloprovincialis from the Atlantic coast (ATL), and on the mussel Brachidontes pharaonis, from MED and RED. The study thereby conducted assays on model systems from three geographical 
regions, aimed at obtaining a comprehensive understanding of the potential application of the tested nanomaterials as novel antifouling agents and of their potential environmental impact.

\section{Materials and Methods}

\subsection{Chemical Compounds}

Eight materials were tested in the framework of the present study (Table 1). They comprised two commercial biocides, zinc ( $\mathrm{ZnPT}$ ) and copper pyrithione (CuPT), provided by Lonza (Basel, Switzerland). Smallmatek (Aveiro, Portugal) developed and produced both the unloaded nanostructured materials (spherical mesoporous silica nanocapsules (SiNC) and Zn-Al layered double hydroxides (LDH)) and the four loaded engineered nanomaterials, corresponding to both biocides individually immobilized/encapsulated in the above nanomaterials (i.e., LDH-ZnPT, LDH-CuPT, SiNC-ZnPT and SiNC-CuPT). The tested nanomaterials were fully characterized by Avelelas et al. [25]. The loading content of $\mathrm{ZnPT}$ is $36 \%$ in the LDH-ZnPT and $4 \%$ in SiNC-ZnPT, whereas for CuPT it is $30 \%$ in the LDH-CuPT and 5\% in the SiNC-CuPT [25].

Table 1. Tested compounds and their chemical specification.

\begin{tabular}{cc}
\hline Compound Abbreviation & Chemical Specification of Compounds \\
\hline ZnPT & ${\text { Zinc pyrithione (Zinc Omadine }{ }^{\mathrm{TM}} \text { ) }}_{\text {CuPT }}$ \\
LDHs & Copper pyrithione (Copper Omadine ${ }^{\mathrm{TM}}$ ) \\
SiNCs & Zn-Al layered double hydroxide (without biocide) \\
SiNC-ZnPT & Hollow silica nanocapules (without biocide) \\
SiNC-CuPT & Zinc pyrithione encapsulated into silica nano-capsules \\
LDH-ZnPT & Copper pyrithione encapsulated into silica nano-capsules \\
LDH-CuPT & Zinc pyrithione immobilized in layered double hydroxide \\
& Copper pyrithione immobilized in layered double hydroxide \\
\hline
\end{tabular}

Stock solutions of the compounds were prepared by vigorous shaking in an ultrasonic bath for $1 \mathrm{~h}$ in order to achieve maximum dispersion and a homogenous dissolution. Exposure concentrations of loaded nanomaterials were calculated according to the biocide loading content in the dry weight of each compound.

\subsection{Antimacrofouling Assays on Mussels}

Antifouling efficacy was tested on M. galloprovincialis and B. pharaonis, following novel assay guidelines [30]. In the ATL, M. galloprovincialis individuals were collected from a rocky area on the Costa Nova beach $\left(40^{\circ} 37^{\prime} \mathrm{N} 8^{\circ} 45^{\prime} \mathrm{W}\right)$, Aveiro, Portugal (July-September 2016). In the MED, mussels were collected from the rocky shore off Hilton Beach $\left(32^{\circ} 05^{\prime} \mathrm{N} 34^{\circ} 46^{\prime} \mathrm{E}\right)$, Tel Aviv (February-October 2015) and in RED from Eilat beach rock $\left(29^{\circ} 32^{\prime} \mathrm{N} 34^{\circ} 57^{\prime} \mathrm{E}\right)$, northern Red Sea (February-October 2015). In all three regions natural seawater was obtained from areas with low human anthropogenic impact and then filtered through $0.45 \mu \mathrm{m}$ filter paper. Following collection, the specimens were placed in aerated aquaria, containing natural filtered seawater at ambient temperature for an acclimation period of $48 \mathrm{~h}$ prior to onset of the experiment. The experimental conditions were conducted under the ambient salinity ( $35 \mathrm{ppt}$ for ATL, 39 for MED, and 40 for RED) and temperature $\left(17-18^{\circ} \mathrm{C}\right.$ for ATL, $18-30^{\circ} \mathrm{C}$ for MED, and $21-27^{\circ} \mathrm{C}$ for RED). Mussels ( $2 \mathrm{~cm}$ length) were individually exposed to the tested compounds for $72 \mathrm{~h}$. They were placed in six-well polystyrene sterile plates, each filled with $10 \mathrm{~mL}$ of the relevant tested concentration solution. Tested concentrations ranged from 0.01 to $100 \mathrm{mg} / \mathrm{L}$ for the ATL mussels ( $n=12$ animals per treatment), MED and RED mussels ( $n=18$ for all treatments). No food or aeration was provided during the experiment. At the end of the experiment, the continued attachment of the mussels to the plate by byssus threads, or their possible mortality, were determined. A recovery test was performed $72 \mathrm{~h}$ later, with the surviving mussels being transferred to new six-well 
plates filled with clean filtered seawater. At the end of the recovery test adhesion and mortality were similarly determined as above.

\subsection{Antimacrofouling Assays on Bryozoan Larvae}

Larvae of the bryozoan Bugula neritina were used for antifouling efficacy assays following novel assay guidelines [30]. Colonies of $B$. neritina were collected from floating docks and buoys at the Tel Aviv ( $32^{\circ} 05^{\prime}$ N $34^{\circ} 46^{\prime}$ E) (MED) and Eilat $\left(29^{\circ} 33^{\prime}\right.$ N $34^{\circ} 58^{\prime}$ E) (RED) marinas. Prior to onset of the experiment, colonies were placed overnight in aerated seawater aquaria under total darkness. The following morning, the colonies were exposed to light for one hour, in order to induce larval release [30]. The larvae congregated on the water-surface, towards the light source and were then collected. Ten larvae were placed in each well filled with $10 \mathrm{~mL}$ of the relevant test solution, with four replicates per condition. The larvae were tested under a concentration range of $1 \times 10^{-6}-100 \mathrm{mg} / \mathrm{L}$ with filtered natural seawater as a negative control. Twenty-four hours post-settlement the larvae were examined under a dissecting microscope.

\subsection{Statistical Analysis}

Data obtained from the assays were used to calculate the half maximal effective concentrations $\left(\mathrm{EC}_{50}\right)$ for each tested compound, assessed according to the percentage of mussels and of bryozoan larvae that had settled during exposure, and examined 24 and $72 \mathrm{~h}$ post-settlement, respectively [27,31]. Mortality of the mussels during exposure to the tested compounds or during the subsequent recovery period in filtered seawater was used to calculate the median lethal concentrations $\left(\mathrm{LC}_{50}\right)$ [31-33]. Results from tested mussels and larvae were considered to be genuine only when more than $90 \%$ of control mussels survived, and more than $90 \%$ of the control larvae succeeded to settle. E/LC 50 were determined using suitable sigmoidal dose response curves through non-regression analysis, performed with the statistical software GraphPad Prism v.6 (GraphPad Software, La Jolla, CA, USA). For each compound and species, the non-linear regression equation that best fits the data was selected considering the $\mathrm{R}^{2}$ value, absolute sum of squares and the $95 \%$ confidence intervals.

\section{Results and Discussion}

\subsection{Unloaded Nanocarriers LDH and SiNC}

The empty carriers $\mathrm{LDH}$ and SiNC yielded the lowest efficacy during the $\mathrm{EC}_{50}$ assays on mussels: LDH with $\mathrm{EC}_{50}$ of 35.7, 15.6, and $106.3 \mathrm{mg} / \mathrm{L}$ for ATL, MED, and RED, respectively, and SiNC with $\mathrm{EC}_{50}$ of 11.8 and $20.9 \mathrm{mg} / \mathrm{L}$ for MED and RED, respectively (Figure 1, Table 2). No EC 50 was found for ATL mussels even when exposed to concentrations of $>100 \mathrm{mg} / \mathrm{L}$.

In the mortality assays of mussels, in both exposure and recovery trails (Figures 2 and 3), LDH caused the lowest mortality of mussels in all geographical regions, featuring $\mathrm{LC}_{50}$ values of $\geq 100 \mathrm{mg} / \mathrm{L}$ (Figure 2). SiNC demonstrated an $\mathrm{LC}_{50}$ value of $\geq 100 \mathrm{mg} / \mathrm{L}$, with the exceptions of $13.2 \mathrm{mg} / \mathrm{L}$ in MED and $33.5 \mathrm{mg} / \mathrm{L}$ in RED (Table 2).

Similarly, the bryozoan assays revealed that LDH yielded the lowest efficacy compared to all other compounds (EC 50 of 9.4 and $4.3 \mathrm{mg} / \mathrm{L}$ for MED and RED, respectively; Figure 4, and Table 3).

Previous studies showed that unloaded $\mathrm{Zn}-\mathrm{Al} \mathrm{LDH}$ has been used to protect metallic coatings from corrosion in order to extend their service life $[15,23]$. In the present study, the unloaded Zn-Al LDH exhibited lower mortality, which indicates it as an ideal carrier for active compounds. Similarly, Avelelas et al. [25] and Martins et al. [34] found that unloaded Zn-Al LDH did not cause mortality when tested on the clam Ruditapes phillipinarum and on M. edulis following $96 \mathrm{~h}$ of exposure. Avelelas et al. [25] also demonstrated the inertness of LDH against the diatom Phaeodactylum tricornutum and the green unicellular alga Tetraselmis chuii. 


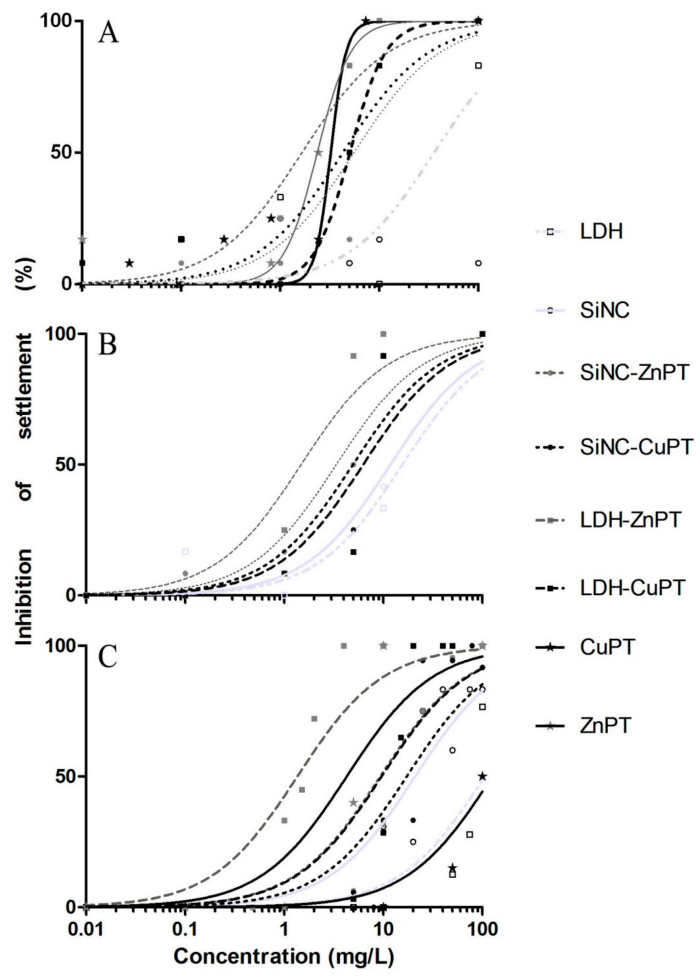

Figure 1. Antimacrofouling efficacy assays following exposure to different concentrations of ENMs on the Atlantic mussel Mytilus galloprovincialis ((A), ATL), and on Brachidontes pharaonis from the Mediterranean Sea ((B), MED) and the Red Sea ((C), RED). ZnPT and CuPT for MED are not presented.

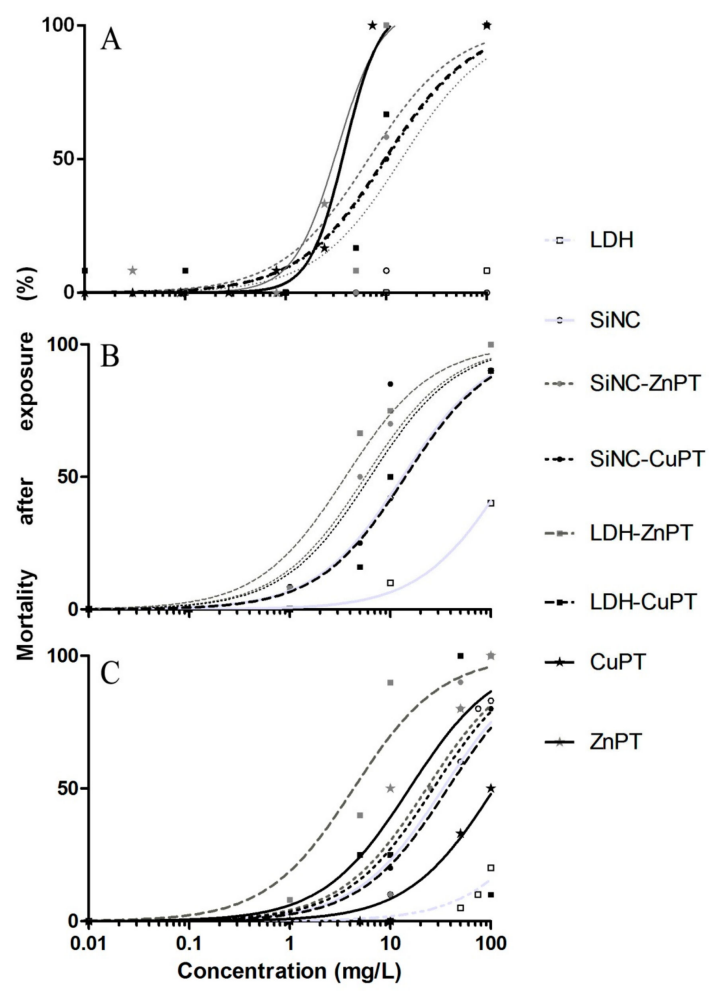

Figure 2. Mortality of the Atlantic mussel Mytilus galloprovincialis ((A), ATL), and of Brachidontes pharaonis from the Mediterranean Sea ((B), MED) and the Red Sea ((C), RED) in efficacy assays following exposure to different concentrations of ENMs. ZnPT and CuPT for MED are not presented. 


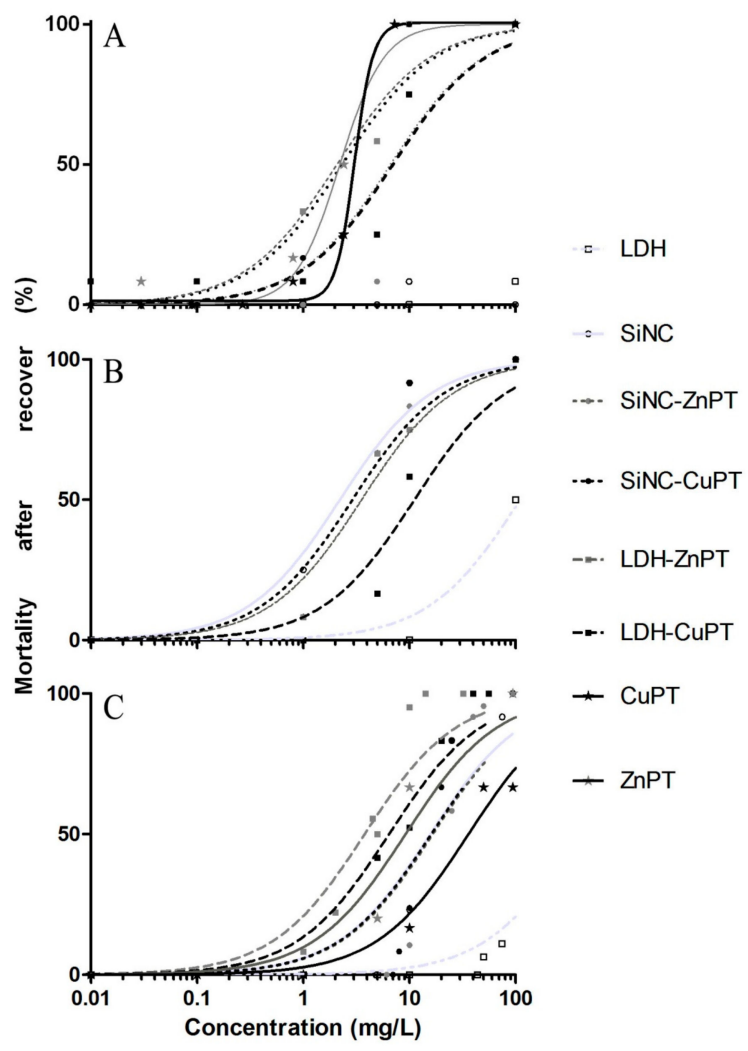

Figure 3. Mortality of the Atlantic mussel Mytilus galloprovincialis ((A), ATL), and of Brachidontes pharaonis from the Mediterranean Sea ((B), MED) and the Red Sea ((C), RED) following recovery assays. $\mathrm{ZnPT}$ and $\mathrm{CuPT}$ for MED are not presented.

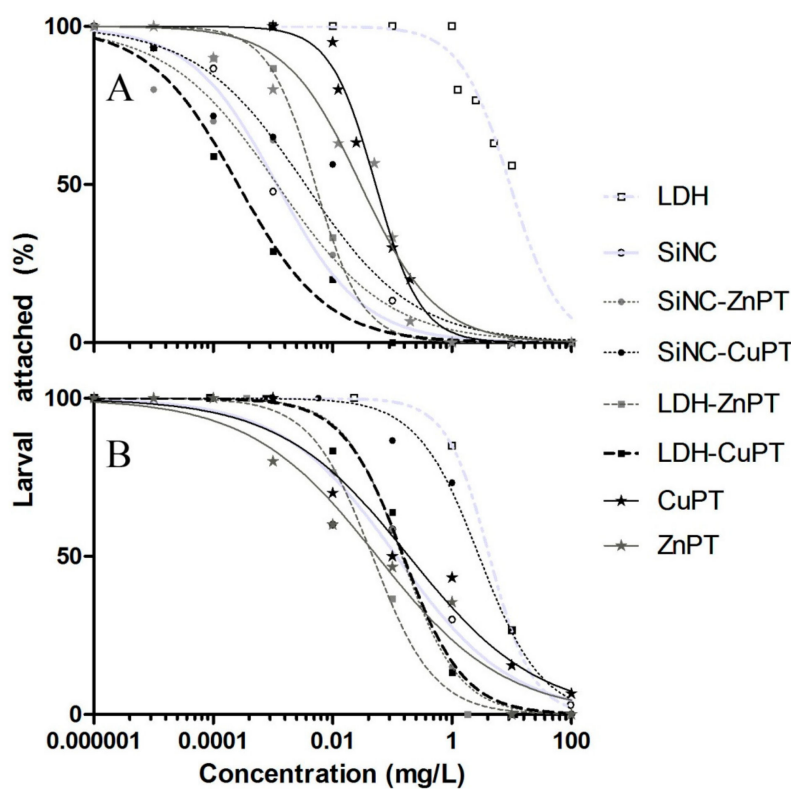

Figure 4. Attachment of Mediterranean ((A), MED) and Red Sea ((B), RED) larvae of Bugula neritina at different concentrations of ENMs. 
Table 2. Tested compounds and their chemical specification.

\begin{tabular}{|c|c|c|c|c|c|c|}
\hline \multirow{3}{*}{ ATL } & \multicolumn{4}{|c|}{ Exposure (72 h) } & \multirow{2}{*}{\multicolumn{2}{|c|}{$\begin{array}{c}\text { Recover }(72 \mathrm{~h}+72 \mathrm{~h}) \\
\text { Mortality }\end{array}$}} \\
\hline & \multicolumn{2}{|c|}{ Efficacy (Inhibition of Settlement) } & \multicolumn{2}{|c|}{ Mortality } & & \\
\hline & $\mathrm{EC}_{50}$ & $95 \%$ CI-EC 50 & $\mathrm{LC}_{50}$ & $95 \%$ CI-LC 50 & $\mathrm{LC}_{50}$ & $95 \%$ CI-LC 50 \\
\hline LDH & 35.7 & $17.54-72.70$ & $>100$ & & $>100$ & \\
\hline SiNC & $>100$ & & $>100$ & & $>100$ & \\
\hline SiNC-ZnPT & 5.5 & $3.47-8.86$ & 14.1 & $9.25-21.64$ & 6.66 & $4.48-9.91$ \\
\hline SiNC-CuPT & 4.3 & $2.88-6.36$ & 10.0 & $6.43-15.59$ & 2.34 & $1.57-3.47$ \\
\hline LDH-ZnPT & 1.6 & $1.07-2.57$ & 6.6 & $4.48-9.91$ & 2.09 & $1.27-3.46$ \\
\hline LDH-CuPT & 5.0 & $3.81-6.67$ & 9.6 & $6.00-15.51$ & 7.04 & $4.30-11.51$ \\
\hline ZnPT & 2.4 & $1.85-3.03$ & 3.2 & $2.57-4.13$ & 2.23 & $1.77-2.82$ \\
\hline CuPT & 3.2 & $1.60-6.56$ & 3.8 & $3.18-4.67$ & 3.07 & $1.90-4.94$ \\
\hline \multirow{3}{*}{ MED } & \multicolumn{4}{|c|}{ Exposure (72 h) } & \multicolumn{2}{|c|}{ Recover $(72 h+72 h)$} \\
\hline & \multicolumn{2}{|c|}{ Efficacy (Inhibition of Settlement) } & \multicolumn{2}{|c|}{ Mortality } & \multicolumn{2}{|c|}{ Mortality } \\
\hline & $\mathrm{EC}_{50}$ & $95 \%$ CI-EC 50 & $\mathrm{LC}_{50}$ & $95 \%$ CI-LC 50 & $\mathrm{LC}_{50}$ & $95 \%$ CI-LC $_{50}$ \\
\hline LDH & 15.6 & $4.9-49.6$ & $>100$ & & $>100$ & \\
\hline SiNC & 11.8 & $6.6-21.0$ & 13.2 & $11.6-15.0$ & 2.2 & $1.1-4.3$ \\
\hline SiNC-ZnPT & 3.4 & $1.7-6.7$ & 5.6 & 3.3-9.7 & 3.5 & $1.5-8.1$ \\
\hline SiNC-CuPT & 4.9 & $1.3-19.0$ & 6.3 & $2.4-16.9$ & 2.9 & $1.4-6.2$ \\
\hline LDH-ZnPT & 1.5 & $0.6-3.6$ & 3.6 & $2.0-6.2$ & 3.6 & $2.1-6.1$ \\
\hline LDH-CuPT & 6.3 & $1.7-23.3$ & 14.1 & $8.4-23.8$ & 11.2 & $5.4-23.3$ \\
\hline \multirow{2}{*}{\multicolumn{7}{|c|}{$\begin{array}{l}\mathrm{ZnPT} \\
\mathrm{CuPT}\end{array}$}} \\
\hline & & & & & & \\
\hline \multirow{3}{*}{ RED } & \multicolumn{4}{|c|}{ Exposure (72 h) } & \multicolumn{2}{|c|}{ Recover $(72 \mathrm{~h}+72 \mathrm{~h})$} \\
\hline & \multicolumn{2}{|c|}{ Efficacy (Inhibition of Settlement) } & \multicolumn{2}{|c|}{ Mortality } & \multicolumn{2}{|c|}{ Mortality } \\
\hline & $\mathrm{EC}_{50}$ & $95 \%$ CI-EC 50 & $\mathrm{LC}_{50}$ & $95 \%$ CI-LC 50 & $\mathrm{LC}_{50}$ & $95 \%$ CI-LC 50 \\
\hline LDH & $>100$ & & $>100$ & & $>>100$ & \\
\hline SiNC & 20.9 & $12.7-34.5$ & 33.5 & $19.6-57.2$ & 15.7 & $6.2-40.0$ \\
\hline SiNC-ZnPT & 9.3 & $4.2-20.8$ & 23.1 & $9.5-55.9$ & 16.6 & $6.5-42.4$ \\
\hline SiNC-CuPT & 17.3 & $8.1-36.7$ & 26.9 & $13.1-55.1$ & 16.1 & $6.3-41.3$ \\
\hline LDH-ZnPT & 1.3 & $0.7-2.5$ & 4.3 & $1.8-10.4$ & 3.8 & $2.1-6.8$ \\
\hline LDH-CuPT & 9.6 & $3.9-23.6$ & 37.4 & $3.4-407.6$ & 6.4 & $3.6-11.4$ \\
\hline $\mathrm{ZnPT}$ & 4.2 & $1.4-12.2$ & 15.5 & $6.0-39.9$ & 9.2 & $4.5-18.4$ \\
\hline CuPT & $>100$ & & $>100$ & & 36.1 & $25.9-50.1$ \\
\hline
\end{tabular}

Table 3. $\mathrm{EC}_{50}$ values for tested compounds on MED and RED bryozoans.

\begin{tabular}{|c|c|c|c|c|}
\hline \multicolumn{5}{|c|}{ Efficacy of B. neritina (Inhibition of Settlement) } \\
\hline \multirow{2}{*}{ Compound } & \multicolumn{2}{|c|}{ MED } & \multicolumn{2}{|c|}{ RED } \\
\hline & $\mathrm{EC}_{50}(\mathrm{mg} / \mathrm{L})$ & $95 \% \mathrm{CI}-\mathrm{EC}_{50}$ & $\mathrm{EC}_{50}(\mathrm{mg} / \mathrm{L})$ & $95 \% \mathrm{CI}-\mathrm{LC}_{50}$ \\
\hline $\mathrm{LDH}$ & 9.4 & $6.0-14.5$ & 4.3 & $4.2-4.4$ \\
\hline SiNC & 0.001 & $0.0006-0.002$ & 0.1 & $0.04-0.3$ \\
\hline SiNC-ZnPT & 0.001 & $0.0004-0.003$ & 0.1 & $0.14-0.15$ \\
\hline SiNC-CuPT & 0.003 & $0.0008-0.01$ & 2.9 & $1.9-4.2$ \\
\hline LDH-ZnPT & 0.005 & $0.003-0.007$ & 0.046 & $0.03-0.06$ \\
\hline LDH-CuPT & 0.0002 & $0.0001-0.0004$ & 0.1 & $0.1-0.2$ \\
\hline $\mathrm{ZnPT}$ & 0.02 & 0.01-0.05 & 0.05 & $0.02-0.1$ \\
\hline $\mathrm{CuPT}$ & 0.05 & $0.04-0.06$ & 0.19 & $0.07-0.4$ \\
\hline
\end{tabular}

In contrast, the efficacy and mortality effects of the unloaded SiNC on MED and RED mussels occurred with similar concentrations as that of the nanomaterial loaded with biocides. Whereas, on the ATL mussels, the compound SiNC did not yield $\mathrm{EC}_{50}$ and $\mathrm{LC}_{50}$ values within the tested concentrations. The higher toxicity of SiNC compared with LDH was expected due to the use of a quaternary ammonium compound (CTAB), which is known to be toxic to aquatic organisms [21,25,35]. Residues of the CTAB could be detected even after several washings, which suggests an increasing toxicity 
of the nanomaterial with increasing exposure concentrations. Both empty nanocarriers displayed antifouling efficacy against the bryozoan larvae, similar to the nanocarriers loaded with biocides (Figures 4 and 5). The antifouling effect of the unloaded nanocarriers was therefore more pronounced on the bryozoan larvae compared to on the adult mussels. It has previously been suggested that larvae are more susceptible than the adult stages to metal ions [36]. In addition, the high ratio of surface area to volume of the larval stages requires active antifouling compounds to be present at a relatively higher concentration and for a longer exposure period than in the case of larger organisms with a low ratio of surface area to volume, such as the adult mussels.

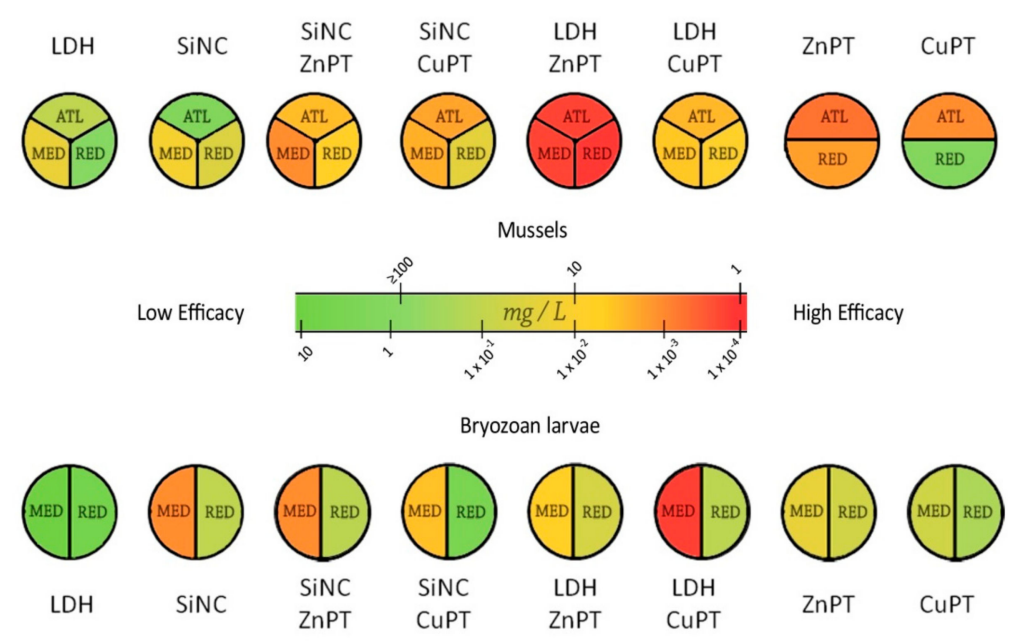

Figure 5. Compilation of antimacrofouling efficacy of ENMs: score based on tested mussels and bryozoan larvae under different concentrations in relation to region.

\subsection{ZnPT and CuPT Loaded Nanomaterials}

The mussel tests revealed LDH-ZnPT as the most effective antimacrofouling compound, with $\mathrm{EC}_{50}$ of 1.6, 1.5, and $1.3 \mathrm{mg} / \mathrm{L}$ for ATL, MED, and RED, respectively, followed by ZnPT, with $\mathrm{EC}_{50}$ ranging from 2.4-4.2 mg/L (Figure 1, Table 2). Preliminary tests on ZnPT with B. pharaonis were carried in the Central Mediterranean Sea (Malta), and yielded $\mathrm{EC}_{50}$ value of $0.2 \mathrm{mg} / \mathrm{L}$ ( $95 \%$ confidence interval $0.03-1.1 \mathrm{mg} / \mathrm{L}$ ). Further studies should be conducted to strengthen knowledge about free pyrithiones efficacy, associated with macrofoulers.

In the bryozoan assays the most effective antimacrofouling compound was LDH-CuPT for the MED bryozoan larvae, featuring $\mathrm{EC}_{50}$ of $2 \times 10^{-4} \mathrm{mg} / \mathrm{L}$ and LDH-ZnPT for RED bryozoan larvae with $\mathrm{EC}_{50}$ of $0.046 \mathrm{mg} / \mathrm{L}$. In both MED and RED, the compound SiNC-ZnPT demonstrated a similar efficacy to the empty nanocarrier SiNC, with $\mathrm{EC}_{50}$ of $0.001 \mathrm{mg} / \mathrm{L}$ in MED, and $0.1 \mathrm{mg} / \mathrm{L}$, in RED. The compound SiNC-CuPT revealed a slightly lower efficacy compared to empty SiNCs (0.003 and $2.9 \mathrm{mg} / \mathrm{L}$ for MED and RED larvae, respectively).

The highest efficacy on the mussels and the bryozoan larvae was demonstrated by LDH-ZnPT. Avelelas et al. [25], who evaluated the lethal effect of LDH, LDH-ZnPT and ZnPT on the sibling Atlantic species M. edulis, also demonstrated that LDH-ZnPT was much lethal $\left(96 \mathrm{~h}-\mathrm{LC}_{50}=0.123 \mathrm{mg} / \mathrm{L}\right)$ than the free biocide $\left(96 \mathrm{~h}-\mathrm{LC}_{50}=0.211 \mathrm{mg} / \mathrm{L}\right)$. The $\mathrm{LC}_{50}$ values of free $\mathrm{ZnPT}$ obtained for the ATL mussels are also in full agreement with a past study testing this biocide on $M$. galloprovincialis $\left(96 \mathrm{~h}-\mathrm{LC}_{50}=4.8 \mathrm{mg} / \mathrm{L} ; 48 \mathrm{~h}-\mathrm{LC}_{50}=14.7 \mathrm{mg} / \mathrm{L}\right)$ [37].

The high efficacy of LDH-ZnPT on mussels may imply its specific mode of activity, mostly related to the biocide $[25,34]$. Consequently, the findings of the present study indicate that the presence of LDH-ZnPT may contribute to the release of ionized PT from $\mathrm{ZnPT}$ and $\mathrm{Zn}^{++}$from the $\mathrm{ZnPT}$ and LDH structure, and therefore explains the lethality caused by LDH-ZnPT on mussels. Although high $\mathrm{Zn}$ intracellular levels may pose risks for the cell, the ionized pyrithiones are highly reactive and 
tend to react with metals and generate new compounds such as CuPT, thus featuring a more toxic chemical mixture $[25,28]$. Pyrithiones are known as powerful inhibitors of several cellular processes, such as membrane transport, ATP levels, and protein synthesis [38]. The biocide ZnPT was found to inhibit ATP synthesis in the mitochondrion by opening up small pores in the membrane [39]. In the yeast Sacharomyces cerevisiae the biocide was found to up-regulate genes related to ion transport and down-regulate genes related to the biosynthesis of cytochrome [40]. ZnPT has been shown to cause accumulation of zinc in the tissues of Mytilus galloprovincialis, being transported from the gills via the hemolymph to the digestive gland, which functions as the main center for metabolic regulation [37]. Sub-lethal concentrations of $\mathrm{ZnPT}$ also activate the antioxidant protective mechanism, including an increased activity of antioxidant enzymes [25,41]. Several authors have connected ZnPT impairment to the uptake of zinc by mitochondria, the binding of ZnPT to the membrane phospholipids [42], and disruption of the membrane electrochemical gradient (due to the inhibition of the membrane proton-linked ATPase) [43].

\subsection{Model Systems in Geographic Perspective}

Nanomaterials present the future technological frontier of surface coatings and industrial development [44]. The current study is the first to engage with the efficacy of novel nanomaterials loaded concomitantly with zinc and copper pyrithiones and tested on marine macrofoulers from several geographical regions. The antifouling nanocarrier technology provides controlled release of the active compounds, enabling the target foulers to be effectively addressed, along with a relatively low release of the compounds into the ambient waters [45]. Mussels have been successfully used as a model system to test the antifouling activity of biocidal compounds by determining both their continued attachment by byssus threads and their mortality $[26,27,46]$. Similarly, the commonly employed model system-larvae of B. neritina, has been used to determine antifouling efficacy $[28,29]$. These two model systems incorporate both adult and larval stages and thus allow determination of both $\mathrm{EC}_{50}$ and $\mathrm{LC}_{50}$ values of the tested compounds. Figure 5 presents a compilation of the antimacrofouling results based on the $\mathrm{EC}_{50}$ values mentioned above (see also Table 2). This figure scores the efficacy of the tested ENMs as was found on both tested mussels and bryozoan larvae under different concentrations in relation to regions.

The current findings are further reinforced by the results of the antifouling assays conducted in three geographic regions (ALT, MED, and RED) representing different environmental conditions.

The three seas feature different environmental conditions, being temperate (ATL), subtropical (MED) and arid-tropical (RED). They differ in annual seawater salinity and annual temperature range (Leandro et al. [47] for ATL, Raveh et al. [48] for MED, and Carlson et al. [49] for RED).

It has been noted previously that temperature and salinity may affect the antifouling performance of a given compound [50-52]. Consequently, the consistent results obtained in the current study, providing similar scores for the antifouling compounds in ATL, MED, and RED, further strengthen our findings for the antifouling features of the tested compounds. The current study has also revealed a differential response of the model systems to the tested compounds in relation to the different geographic regions. RED mussels and bryozoan larvae were affected by a higher range of concentrations than ATL and MED species, being such differences more pronounced in bryozoan larvae than in mussels.

Therefore, the current results demonstrate the efficacy of the tested compounds under a variety of environmental conditions and thus reflect their potency of being antifoulants in a range of geographic regions featuring different fouling pressures. Nonetheless, further laboratory studies should be conducted in order to test the efficacy of the nanocarriers under controlled salinity and temperature range. 


\section{Conclusions}

The present study offers for the first time a comparison between the antifouling activity of nanocarriers loaded with the booster biocides zinc pyrithione ( $\mathrm{ZnPT}$ ) and copper pyrithione (CuPT) against macrofoulers from three geographical regions. The promising results from the application of layered doubled hydroxides (LDH) incorporated with ZnPT can be of major benefit, as a lower quantity of booster biocide is required than used with other compounds to date. The current findings are expected to stimulate further studies in order to understand how nanocarriers act on the cellular and subcellular levels in the target organisms, better understanding their mode of activity and environmental impact.

Acknowledgments: We would like to thank the Interuniversity Institute for Marine Sciences in Eilat (IUI) for logistic support and kind hospitality and T. Shaler for assisting in the antifouling assays. The collection of animals complied with a permit issued by the Israel Nature and National Parks Protection Authority. This study was supported by the EU FP7 Project "Low-toxic cost-efficient environment-friendly antifouling materials" (OCEAN for Tomorrow) under Grant Agreement No. 612717 and in part by the Israel Cohen Chair in Environmental Zoology to YB. Roberto Martins and João Tedim benefitted from a Post-Doctoral grant (SFRH/BPD/93225/2013) and a Researcher grant (IF/00347/2013), respectively, awarded by the Portuguese Science Foundation (FCT), funded by the Human Potential Operational Programme (POPH) through QREN and European Social Fund (ESF) and by national funds through the Portuguese Ministry of Education and Science. Susana Loureiro has a fellowship from the program 'Science without Borders' from CAPES (Project \#106/2013). We also acknowledge for the financial support to CESAM (UID/AMB/50017) and CICECO-Aveiro Institute of Materials (POCI-01-0145-FEDER-007679; UID/CTM/50011/2013) through national funds and co-funding by the FEDER, within the PT2020 Partnership Agreement and Compete 2020.

Author Contributions: E.G.-H. and Y.B. designed the research. E.G.-H., R.M., T.O., C.P., and I.P. performed the research. E.G.-H. and R.M. analyzed the data. E.G.-H., R.M., and Y.B. wrote the manuscript. All authors reviewed and edited the manuscript.

Conflicts of Interest: There are no conflicts of interest to declare.

\section{References}

1. Wahl, M. Marine epibiosis. I. Fouling and antifouling: Some basic aspects. Mar. Ecol. Prog. Ser. 1989, 58, 175-189. [CrossRef]

2. Railkin, A.I. Marine Biofouling: Colonization Processes and Defenses; CRC Press: Boca Raton, FL, USA; London, UK, 2003; ISBN 0-8493-1419-4.

3. Chambers, L.D.; Stroke, K.R.; Walsh, F.C.; Wood, R.J.K. Modern approaches to marine antifouling coatings. Surf. Coat. Technol. 2006, 201, 3642-3652. [CrossRef]

4. Callow, J.A.; Callow, M.E. Trends in the development of environmentally friendly fouling-resistant marine coatings. Nat. Commun. 2011, 2, 244. [CrossRef] [PubMed]

5. Kirschner, C.M.; Brennan, A.B. Bio-inspired antifouling strategies. Annu. Rev. Mater. Res. 2012, 42, $211-229$. [CrossRef]

6. Banerjee, I.; Pangule, R.C.; Kane, R.S. Antifouling coatings: Recent developments in the design of surfaces that prevent fouling by proteins, bacteria, and marine organisms. Adv. Mater. 2011, 23, 690-718. [CrossRef] [PubMed]

7. Price, A.R.; Readman, J.W. 12 Booster biocide antifoulants: Is history repeating itself? In Late Lessons from Early Warnings: Science, Precaution, Innovation; European Environment Agency: Copenhagen, Denmark, 2013; ISBN 978-92-9213-349-8.

8. Huang, X.; Marsh, K.L.; McVerry, B.T.; Hoe, E.M.; Kaner, R.B. Low-Fouling Antibacterial Reverse Osmosis Membranes via Surface Grafting of Graphene Oxide. ACS Appl. Mater. Interfaces 2016, 23, 14334-14338. [CrossRef] [PubMed]

9. Kang, S.; Asatekin, A.; Mayers, A.M.; Elimelech, M. Protein antifouling mechanisms of PAN UF membranes incorporating PAN-g-PEO additive. J. Membr. Sci. 2007, 296, 42-50. [CrossRef]

10. Dobretsov, S.; Teplitski, M.; Bayer, M.; Gunasekera, S.; Proksch, P.; Paul, V.J. Inhibition of marine biofouling by bacterial quorum sensing inhibitors. Biofouling 2011, 27, 413-427. [CrossRef] [PubMed]

11. Fusetani, N. Antifouling marine natural products. Nat. Prod. Rep. 2011, 28, 400-410. [CrossRef] [PubMed] 
12. Dobretsov, S. Inhibition and Induction of Marine Biofouling by Biofilms; Springer: Berlin/Heidelberg, Germany, 2009; Volume 4, ISBN 978-3-540-69796-1.

13. Hu, Y.; Zheng, X.T.; Chen, J.S.; Zhou, M.; Li, C.M.; Lou, X.J. Silica-based complex nanorattles as multifunctional carrier for anticancer drug. J. Mater. Chem. 2011, 21, 8052-8056. [CrossRef]

14. Zeng, G.; Xing, Y.; Gao, J.; Wang, Z.; Zhang, X. Unconventional layer-by-layer assembly of graphene multilayer films for enzyme-based glucose and maltose biosensing. Langmuir 2010, 26, 15022-15026. [CrossRef] [PubMed]

15. Tedim, J.; Poznyak, S.K.; Kuznetsova, A.; Raps, D.; Hack, T.; Zheludkevich, M.L.; Ferreira, M.G.S. Enhancement of active corrosion protection via combination of inhibitor-loaded nanocontainers. ACS Appl. Mater. Interfaces 2010, 2, 1528-1535. [CrossRef] [PubMed]

16. Geiger, T.; Delavy, P.; Hany, R.; Schleuniger, J.; Zinn, M. Encapsulated zosteric acid embedded in poly [3-hydroxyalkanoate] coatings-Protection against biofouling. Polym. Bull. 2004, 52, 65-72. [CrossRef]

17. Hart, R.L.; Virgallito, D.R.; Work, D.E. Microencapsulation of Biocides and Antifouling Agents. U.S. Patent 7938897, 5 October 2011.

18. Szabó, T.; Molnár-Nagy, L.; Bognár, J.; Nyikos, L.; Telegdi, J. Self-healing microcapsules and slow release microspheres in paints. Prog. Org. Coat. 2011, 72, 52-57. [CrossRef]

19. Zheng, Z.; Huang, X.; Schenderlein, M.; Borisova, D.; Cao, R.; Möhwald, H.; Shchukin, D. Self-Healing and Antifouling Multifunctional Coatings Based on $\mathrm{pH}$ and Sulfide Ion Sensitive Nanocontainers. Adv. Funct. Mater. 2013, 23, 3307-3314. [CrossRef]

20. Nooney, R.I.; Thirunavukkarasu, D.; Chen, Y.; Josephs, R.; Ostafin, A.E. Synthesis of nanoscale mesoporous silica spheres with controlled particle size. Chem. Mater. 2002, 14, 4721-4728. [CrossRef]

21. Maia, F.; Tedim, J.; Lisenkov, A.D.; Salak, A.N.; Zheludkevich, M.L.; Ferreira, M.G. Silica nanocontainers for active corrosion protection. Nanoscale 2012, 4, 1287-1298. [CrossRef] [PubMed]

22. Maia, F.; Silva, A.P.; Fernandes, S.; Cunha, A.; Almeida, A.; Tedim, J.; Zheludkevich, M.L.; Ferreira, M.G.S. Incorporation of biocides in nanocapsules for protective coatings used in maritime applications. Chem. Eng. J. 2015, 270, 150-157. [CrossRef]

23. Zheludkevich, M.L.; Poznyak, S.K.; Rodrigues, L.M.; Raps, D.; Hack, T.; Dick, L.F.; Nunes, T.; Ferreira, M.G.S. Active protection coatings with layered double hydroxide nanocontainers of corrosion inhibitor. Corros. Sci. 2010, 52, 602-611. [CrossRef]

24. Newman, S.P.; Jones, W. Synthesis, characterization and applications of layered double hydroxides containing organic guests. New J. Chem. 1998, 22, 105-115. [CrossRef]

25. Avelelas, F.; Martins, R.; Oliveira, T.; Maia, F.; Malheiro, E.; Soares, A.; Loureiro, S.; Tedim, J. Efficacy and Ecotoxicity of Novel Anti-Fouling Nanomaterials in Target and Non-Target Marine Species. Mar. Biochechnol. 2017, 19, 164-174. [CrossRef] [PubMed]

26. Ina, K.; Takasawa, R.; Yagi, A.; Yamashita, N.; Ltoh, H.; Sakata, K. An improved assay method for antifouling substances using the blue mussel, Mytilus edulis. Agric. Biol. Chem. 1989, 53, 3319-3321.

27. Wilsanand, V.; Wagh, A.B.; Bapuji, M. Effect of alcohol extracts of demospongiae on growth of periphytic diatoms. Indian J. Mar. Sci. 1999, 28, 274-279.

28. Bryan, P.J.; Rittschof, D.; Qian, P.Y. Settlement inhibition of bryozoan larvae by bacterial films and aqueous leachates. Bull. Mar. Sci. 1997, 61, 849-857.

29. Dahms, H.U.; Dobretsov, S.; Qian, P.Y. The effect of bacterial and diatom biofilms on the settlement of the bryozoan Bugula neritina. J. Exp. Mar. Biol. Ecol. 2004, 313, 191-209. [CrossRef]

30. Brancato, M.S.; Woollacott, R.M. Effect of microbial films on settlement of bryozoan larvae (Bugula simplex, B. stolonifera and B. turrita). Mar. Biol. 1982, 71, 51-56. [CrossRef]

31. Qi, S.H.; Xu, Y.; Gao, J.; Qian, P.Y.; Zhang, S. Antibacterial and antilarval compounds from marine bacterium Pseudomonas rhizosphaerae. Ann. Microbiol. 2009, 59, 229. [CrossRef]

32. Clarke, G.L. Poisoning and recovery in barnacles and mussels. Biol. Bull. 1947, 92, 73-91. [CrossRef] [PubMed]

33. Ramasamy, M.S.; Murugan, A. Fouling deterrent chemical defense in three muricid gastropod egg masses from the Southeast coast of India. Biofouling 2007, 23, 259-265. [CrossRef] [PubMed]

34. Martins, R.; Oliveira, T.; Santos, C.; Kuznetsova, A.; Ferreira, V.; Avelelas, F.; Caetano, A.; Tedim, J.; Ferreira, M.; Freitas, R.; et al. Effects of a novel anticorrosion engineered nanomaterial on the bivalve Ruditapes philippinarum. Environ. Sci. Nano 2017, 4, 1064-1076. [CrossRef] 
35. Zhang, C.; Cui, F.; Zeng, G.M.; Jiang, M.; Yang, Z.Z.; Yu, Z.G.; Zhu, M.Y.; Shen, L.Q. Quaternary ammonium compounds (QACs): A review on occurrence, fate and toxicity in the environment. Sci. Total Environ. 2015, 518, 352-362. [CrossRef] [PubMed]

36. Connor, P.M. Acute toxicity of heavy metals to some marine larvae. Mar. Pollut. Bull. 1972, 3, $190-192$. [CrossRef]

37. Marcheselli, M.; Cecilia, R.; Mauri, M. Novel antifouling agent zinc pyrithione: Determination, acute toxicity, and bioaccumulation in marine mussels (Mytilus galloprovincialis). Environ. Toxicol. Chem. 2010, 29, 2583-2592. [CrossRef] [PubMed]

38. Chandler, C.J.; Segel, I.H. Mechanism of the antimicrobial action of pyrithione: Effects on membrane transport, ATP levels, and protein synthesis. Antimicrob. Agents Chemother. 1978, 14, 60-68. [CrossRef] [PubMed]

39. Bragadin, M.; Manente, S.; Marton, D.; Cima, F.; Rigobello, M.P.; Bindoli, A. The interaction of zinc pyrithione with mitochondria from rat liver and a study of the mechanism of inhibition of ATP synthesis. Appl. Organomet. Chem. 2003, 17, 869-874. [CrossRef]

40. Yasokawa, D.; Murata, S.; Iwahashi, Y.; Kitagawa, E.; Kishi, K.; Okumura, Y.; Iwahashi, H. DNA microarray analysis suggests that zinc pyrithione causes iron starvation to the yeast Saccharomyces cerevisiae. J. Biosci. Bioeng. 2010, 109, 479-486. [CrossRef] [PubMed]

41. Trevisan, R.; Flesch, S.; Mattos, J.J.; Milani, M.R.; Bainy, A.C.D.; Dafre, A.L. Zinc causes acute impairment of glutathione metabolism followed by coordinated antioxidant defenses amplification in gills of brown mussels Perna perna. Comp. Biochem. Physiol. C Toxicol. Pharmacol. 2014, 159, 22-30. [CrossRef] [PubMed]

42. Dinning, A.J.; Al-Adam, I.S.I.; Austin, P.; Charlton, M.; Collier, P.J. Pyrithione biocide interactions with bacterial phospholipid head groups. J. Appl. Microbiol. 1998, 85, 132-140. [CrossRef] [PubMed]

43. Emolayeva, E.; Sanders, D. Mechanism of pyrithione-induced membrane depolarization in Neurospora crassa. Appl. Environ. Microbiol. 1995, 61, 3385-3390.

44. Busnaina, A.A.; Mead, J.; Isaacs, J.; Somu, S. Nanomanufacturing and sustainability: Opportunities and challenges. J. Nanopart. Res. 2013, 15, 1984. [CrossRef]

45. Shutava, T.G.; Fakhrullin, R.F.; Lvov, Y.M. Spherical and tubule nanocarriers for sustained drug release. Curr. Opin. Pharmacol. 2014, 18, 141-148. [CrossRef] [PubMed]

46. Prakash, S.; Ramasubburayan, R.; Iyapparaj, P.; Arthi, A.P.R.; Ahila, N.K.; Ramkumar, V.S.; Immanuel, G.; Palavesam, A. Environmentally benign antifouling potentials of triterpene-glycosides from Streptomyces fradiae: A mangrove isolate. RSC Adv. 2015, 5, 29524-29534. [CrossRef]

47. Leandro, S.M.; Tiselius, P.; Queiroga, H. Spatial and temporal scales of environmental forcing of Acartia populations (Copepoda: Calanoida) in the Canal de Mira (Ria de Aveiro, Portugal). ICES J. Mar. Sci. 2013, 71, 585-596. [CrossRef]

48. Raveh, O.; David, N.; Rilov, G.; Rahav, E. The temporal dynamics of coastal phytoplankton and bacterioplankton in the Eastern Mediterranean Sea. PLoS ONE 2015, 10, e0140690. [CrossRef] [PubMed]

49. Carlson, D.F.; Fredj, E.; Gildor, H. The annual cycle of vertical mixing and restratification in the Northern Gulf of Eilat/Aqaba (Red Sea) based on high temporal and vertical resolution observations. Deep Sea Res. Part 1 Oceanogr. Res. Pap. 2014, 84, 1-17. [CrossRef]

50. Sogorb, A.; Andreu-Moliner, E.S.; Almar, M.M.; del Rame, J.; Núñez, A. Temperature-toxicity relationships of fluvalinate (Synthetic pyrethroid) on Procambarus clarkii (Girard) under laboratory conditions. Bull. Environ. Contam. Toxicol. 1988, 40, 13-17. [CrossRef] [PubMed]

51. Hall, L.W.; Ziegenfuss, M.C.; Anderson, R.D.; Lewis, B.L. The effect of salinity on the acute toxicity of total and free cadmium to a Chesapeake Bay copepod and fish. Mar. Pollut. Bull. 1995, 30, 376-384. [CrossRef]

52. Kwok, K.W.H.; Leung, K.M. Toxicity of antifouling biocides to the intertidal harpacticoid copepod Tigriopus japonicus (Crustacea, Copepoda): Effects of temperature and salinity. Mar. Pollut. Bull. 2005, 51, 830-837. [CrossRef] [PubMed]

(C) 2018 by the authors. Licensee MDPI, Basel, Switzerland. This article is an open access article distributed under the terms and conditions of the Creative Commons Attribution (CC BY) license (http:/ / creativecommons.org/licenses/by/4.0/). 